\title{
Bioindicators of changes in water quality on coral reefs: review and recommendations for monitoring programmes
}

\author{
T. F. Cooper $\cdot$ J. P. Gilmour $\cdot$ K. E. Fabricius
}

Received: 2 December 2008/Accepted: 8 May 2009/Published online: 2 June 2009

(C) Springer-Verlag 2009

\begin{abstract}
Effective environmental management requires monitoring programmes that provide specific links between changes in environmental conditions and ecosystem health. This article reviews the suitability of a range of bioindicators for use in monitoring programmes that link changes in water quality to changes in the condition of coral-reef ecosystems. From the literature, 21 candidate bioindicators were identified, whose responses to changes in water quality varied spatially and temporally; responses ranged from rapid (hours) changes within individual corals to long-term (years) changes in community composition. From this list, the most suitable bioindicators were identified by determining whether responses were (i) specific, (ii) monotonic, (iii) variable, (iv) practical and (v) ecologically relevant to management goals. For long-term monitoring programmes that aim to quantify the effects of chronic changes in water quality, 11 bioindicators were selected: symbiont photophysiology, colony brightness, tissue thickness and surface rugosity of massive corals, skeletal elemental and isotopic composition, abundance of
\end{abstract}

Environment Editor Prof. Rob van Woesik

T. F. Cooper $(\bowtie) \cdot$ J. P. Gilmour

Australian Institute of Marine Science, Botany Building (M096), University of Western Australia, 35 Stirling Highway, Crawley, WA 6009, Australia

e-mail: t.cooper@aims.gov.au

T. F. Cooper

School of Marine and Tropical Biology, and ARC Centre of Excellence for Coral Reef Studies, James Cook University, Townsville, QLD 4810, Australia

K. E. Fabricius

Australian Institute of Marine Science, PMB 3 Townsville MC, Townsville, QLD 4810, Australia macro-bioeroders, micro- and meiobenthic organisms such as foraminifera, coral recruitment, macroalgal cover, taxonomic richness of corals and the maximal depth of coralreef development. For short-term monitoring programmes, or environmental impact assessments that aim to quantify the effects of acute changes in water quality, a subset of seven of these bioindicators were selected, including partial mortality. Their choice will depend on the specific objectives and the timeframe available for each monitoring programme. An assessment framework is presented to assist in the selection of bioindicators to quantify the effects of changing water quality on coral-reef ecosystems.

Keywords Environmental monitoring .

Sublethal effects $\cdot$ Nutrients $\cdot$ Sedimentation $\cdot$ Turbidity

\section{Introduction}

Disturbances of coral reefs are caused by a complex combination of stressors including those arising from climate change, diseases, predation, destructive fishing practices, storms and changes in water quality. Many of these stressors are increasingly acting over regional and/or global scales; therefore, maintaining the resilience of coral communities will require a reduction in local, but manageable, impacts such as altered water quality. However, in some parts of the world, nutrient and sediment inputs to coral reefs have increased several-fold over the last 150 years (e.g. Richmond 1993; McCulloch et al. 2003) causing reduced coral recruitment (Loya 1976; Babcock and Davies 1991; Loya et al. 2004), modified trophic structures (Lapointe 1997; Fabricius 2005), altered biodiversity (van Woesik et al. 1999) and coral mortality (Kline et al. 2006). These processes can transfer the competitive advantage 
away from reef-building corals leading to trophic dominance by assemblages of macroalgae (Schaffelke 1999) once productivity exceeds rates of herbivory (McCook 1999). Therefore, monitoring programmes require a suite of bioindicators that can effectively quantify the link between changes in water quality and the condition of coral-reef ecosystems.

The use of bioindicators provides a number of significant advantages over direct measurements of water quality. For example, a direct measurement of water quality provides information about the condition of the water column at that particular point in time. Moreover, if the frequency of sampling is limited, or is weather-dependant and constrained by safety considerations, then important information on the effects of acute episodic events that can strongly influence the structure of coral communities may not be quantified (e.g. terrestrial discharges during floods or the resuspension of sediments during strong winds). These issues are addressed with the use of appropriate bioindicators that provide a time-integrated measure (from time periods of minutes to years) of the effects of changes in water quality on coral reefs. Given the range of natural and anthropogenic factors that influence a complex ecosystem such as a coral reef, compared with a single bioindicator a suite of bioindicators of cellular, organismal and community effects will more effectively attribute ecological change to changes in specific environmental conditions (Erdmann and Caldwell 1997; Jameson et al. 1998). Suites of bioindicators and predictive models have been developed and applied successfully for assessments of ecosystem health in estuarine and freshwater systems. For example, models such as AUSRIVAS (Simpson and Norris 2000) assess ecosystem health based on assemblages of freshwater macroinvertebrates, and the SIGNAL biotic index uses the presence or absence of families of macroinvertebrates to infer levels of exposure of river systems to chemical pollutants (Chessman et al. 1997). Few studies have assessed the suitability of potential bioindicators or their application to an index of coral-reef ecosystem health (Brown 1997). Three notable exceptions exist. First, Risk et al. (2001) used the diversity of certain invertebrates (e.g. stomatopods and amphipods), measures of bioerosion and geochemical markers to quantify the health of coral-reef ecosystems exposed to terrestrial runoff. Second, Jameson et al. (2001) developed Indexes of Biotic Integrity (IBI's) for coral reefs combining several metrics for sessile epibenthos, benthic macroinvertebrates, fish, marine vegetation, phytoplankton and zooplankton. Third, Jameson and Kelty (2004) reviewed potential bioindicators of changes in sediments, nutrients, heavy metals, herbicides, pesticides and bacterial exposure, as well as multi-metric bioindicators of the combination of stressors on scleractinian and non-scleractinian communities.
This review builds upon these previous studies by further investigating the desirable characteristics of a suite of bioindicators and their response time to changes in water quality. Specifically, the aim of this review was to assess and identify the bioindicators that are potentially most appropriate for use in monitoring programmes that link changes in water quality (i.e. dissolved and/or particulate nutrients, rate of sedimentation, turbidity, benthic irradiance, or other pollutants such as herbicides and pesticides) to changes in the condition of coral-reef ecosystems. Candidate bioindicators were first grouped according to the ecological level at which the response to changes in water quality could be measured, i.e. genetic/colony, population or community level. This initial grouping also corresponded to differences in response times, with bioindicators at the genetic/colony level characterised by rapid responses to changes in water quality, whilst responses at higher levels of ecological organisation generally occurred over longer time periods. This has important implications for the selection of bioindicators because the timeframe available for monitoring can vary from years or decades for some long-term monitoring programmes, and weeks or months for short-term monitoring programmes such as environmental impact assessments (EIA). Within this context, the scientific literature was used to rank the suitability of bioindicators according to a framework that assessed whether responses to changes in water quality were (i) specific, (ii) monotonic, (iii) variable, (iv) practical and (v) relevant to management goals for long- and shortterm monitoring programmes.

\section{Desirable characteristics and selection of bioindicators}

A change in water quality may be chronic (e.g. altered runoff regime) or acute (e.g. dredging or flood events), so an important characteristic in the selection of any bioindicator is the time taken for the biological response to manifest at the genetic/colony, population or community level. Both the duration of response initiation and the recovery period can range from near-instantaneous to decades. An important distinction, therefore, is to differentiate between measures suitable for detecting effects during or shortly after exposure to a change in water quality (i.e. rapidly, whereby the response initiation and recovery from an event occurs within hours to weeks), and those better suited to detecting cumulative effects over prolonged periods of time (i.e. slowly, whereby initiation of and recovery from response may take months to years). There are both advantages and disadvantages to rapid and slow response times in bioindicators according to their application. A rapid response could be considered desirable as an 'early warning' indicator of change, i.e. a sublethal response used in short-term monitoring programmes that 
incorporate reactive management strategies to mitigate the effects of any further changes in water quality. This is offset, however, by the high level of sampling intensity and replication required to obtain accurate estimates of a response that could change over days to weeks. Conversely, a bioindicator responding over a longer timescale may not provide an early warning of change, but be particularly useful for monitoring chronic exposures, as these types of bioindicators are likely to have low-natural variability and require fewer samples to detect ecological change. Most importantly, the response time of a bioindicator to a change in water quality must be comparable to the timeframe of the disturbance being measured.

In order to select a bioindicator objectively requires a set of selection criteria. Here, five key criteria were used to rank the suitability of bioindicators for assessing changes in water quality on coral reefs (Table 1; modified from Jones and Kaly 1996; Erdmann and Caldwell 1997; Jameson et al. 1998). First, specificity is the extent to which the changes in the bioindicator respond to changes in water quality, and not to other environmental conditions (Fig. 1a). Second, monotonicity is the extent to which the magnitude of the changes in the bioindicator are proportional to the intensity and duration of the changes in water quality, which is evident in the shape of the dose-response relationship (Fig. 1b, c). Third, variability is the extent of natural variation of the bioindicator in the absence of changes in water quality. A bioindicator that displays patterns of seasonal or temporal variability might still be suitable for monitoring programmes provided that the effect size at the time and location of the disturbance differs significantly compared with variability at reference

Table 1 Criteria for selection of bioindicators to assess effects of changes in water quality on corals and coral communities

\begin{tabular}{ll}
\hline Criteria & Definition \\
\hline Specificity & $\begin{array}{c}\text { Biological response is specific to the stressor of } \\
\text { interest and not to other environmental stressors }\end{array}$ \\
Monotonicity & $\begin{array}{c}\text { The magnitude of the biological response should } \\
\text { reflect the intensity and duration of the stressor of } \\
\text { interest }\end{array}$ \\
Variability & $\begin{array}{c}\text { Biological responses should be consistent at a range of } \\
\text { spatial and temporal scales. Ideally, there should be } \\
\text { low background variability although a change in } \\
\text { variance can itself be used as an indicator of an } \\
\text { impact }\end{array}$ \\
Practicality & $\begin{array}{c}\text { Measurements of biological responses should be cost } \\
\text { effective, easy to measure, non-destructive and } \\
\text { observer independent }\end{array}$ \\
Relevance & $\begin{array}{c}\text { Biological response should be ecologically relevant } \\
\text { and important in public perception to assist } \\
\text { communication }\end{array}$ \\
\hline
\end{tabular}

Modified from Jones and Kaly (1996), Erdmann and Caldwell (1997), and Jameson et al. (1998) locations (Fig. 1d). Fourth, practicality is the extent to which the changes in the bioindicator are easily quantified, and depends on cost, observer independence, level of expertise and the spatial and temporal scales required for application. Last, relevance refers to ecological relevance as well as to relevance in public perception, which will assist in the communication of the results to a wide range of end-users.

Bioindicators of the effects of changes in water quality on coral reefs

From the many bioindicators presented in the literature, 21 candidate bioindicators were short-listed for potential use in monitoring programmes on coral reefs. The next section and Table 2 provide a brief description of the main properties of these bioindicators. In order to facilitate the systematic comparison of bioindicators and to assess their suitability to detect either chronic or acute changes in water
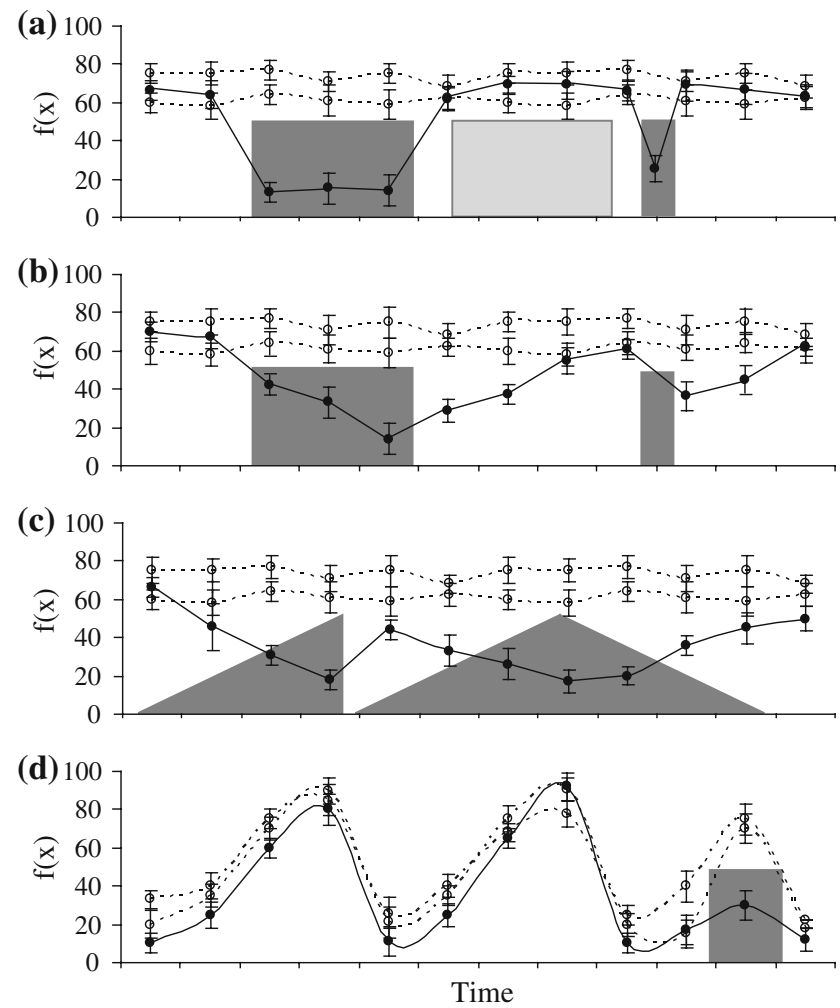

Fig. 1 Response of a hypothetical bioindicator to a disturbance (dark grey areas represent the disturbance in question; light grey areas represent other disturbances). A suitable bioindicator must detect differences between a disturbed state (solid line) and reference states (dashed lines). a response of a bioindicator with high specificity, $\mathbf{b}$ and $\mathbf{c}$ monotonic dose-response relationships whereby the magnitude of change of the bioindicator is proportional to the intensity and duration of the disturbance, $\mathbf{d}$ responses at impact locations must differ from those at reference locations if bioindicators that vary temporally are used in monitoring programmes 
Table 2 Examples of studies examining coral reef bioindicators to changing water quality at the level of individual colonies, populations and communities on coral reefs

\begin{tabular}{|c|c|c|c|}
\hline Bioindicator & Stressor & Response & Source \\
\hline \multicolumn{4}{|l|}{ Genetic/colony measures } \\
\hline Gene expression & $\begin{array}{l}\text { Heavy metals, } \\
\text { sedimentation }\end{array}$ & $\begin{array}{l}\text { Up-regulation of } 14 \text { of } 32 \text { stress genes on cDNA array of Diploria strigosa } \\
\text { sampled in a bay adjacent to a municipal dump. Elevated expression of } \\
\text { uPAR transcripts consistent with genes expressed during sedimentation } \\
\text { stress }\end{array}$ & $\begin{array}{l}\text { (Morgan et al. } \\
\text { 2005) }\end{array}$ \\
\hline RNA/DNA ratio & $\begin{array}{l}\text { Turbidity and light } \\
\text { attenuation }\end{array}$ & $\begin{array}{l}\text { Increasing RNA/DNA ratio related to irradiance for massive Porites spp. } \\
\text { sampled at two of three locations in Indonesia. Elevated RNA/DNA ratio } \\
\text { at turbid locations suggests greater metabolic activity at higher suspended } \\
\text { particle loads }\end{array}$ & $\begin{array}{l}\text { (Meesters et al. } \\
\text { 2002) }\end{array}$ \\
\hline $\begin{array}{l}\text { Symbiont } \\
\text { photophysiology }\end{array}$ & Herbicides & $\begin{array}{l}F_{\mathrm{v}} / F_{\mathrm{m}} \text { in four species of coral (Acropora formosa, Montipora digitata, } \\
\quad \text { Porites cylindrica, Seriatopora hystrix) reduced by } 50 \% \text { within } 60-90 \mathrm{~min} \\
\quad \text { of exposure to diuron }\left(10 \mu \mathrm{g}^{-1}\right) \text { compared with controls }\end{array}$ & (Jones et al. 2003) \\
\hline $\begin{array}{l}\text { Concentration of } \\
\text { chlorophyll } a\end{array}$ & $\begin{array}{l}\text { Dissolved } \\
\text { inorganic } \\
\text { nutrients }\end{array}$ & $\begin{array}{l}\text { Mean chl. } a\left(\mathrm{mg} \text { g protein }{ }^{-1}, \pm \mathrm{SE}\right): \text {. pistillata, Control } 5.6 \pm 3.14, \mathrm{NH}_{4} \\
(20 \mu \mathrm{M}) 19.4 \pm 8.97 . \text { S. hystrix, Control } 8.75 \pm 4.04, \mathrm{NH}_{4}(20 \mu \mathrm{M}) \\
13.5 \pm 4.49\end{array}$ & $\begin{array}{l}\text { (Hoegh-Guldberg } \\
\text { and Smith 1989) }\end{array}$ \\
\hline Density of symbionts & $\begin{array}{l}\text { Dissolved } \\
\text { inorganic } \\
\text { nutrients }\end{array}$ & $\begin{array}{l}\text { Mean symbiont density }\left(10^{6} \text { cells } \mathrm{mg} \text { protein }{ }^{-1}, \pm \mathrm{SE}\right): \text { S. pistillata, Control } \\
0.55 \pm 0.12, \mathrm{NH}_{4}(20 \mu \mathrm{M}) 1.49 \pm 0.25 . \text { S. hystrix, Control } 2.11 \pm 1.03 \\
\mathrm{NH}_{4}(20 \mu \mathrm{M}) 2.78 \pm 1.55\end{array}$ & $\begin{array}{l}\text { (Hoegh-Guldberg } \\
\text { and Smith 1989) }\end{array}$ \\
\hline Lipid content & Inshore-offshore & $\begin{array}{l}\text { Porites porites, nearshore lipid content } \sim 11 \% \text { of tissue DW, offshore lipid } \\
\text { content } \sim 8 \% \text { of tissue DW }\end{array}$ & $\begin{array}{l}\text { (Harland et al. } \\
\text { 1992) }\end{array}$ \\
\hline Lipid content & Turbidity & Goniastrea retiformis and $P$. cylindrica, lipid content reduced by shading & $\begin{array}{l}\text { (Anthony and } \\
\text { Fabricius 2000) }\end{array}$ \\
\hline Tissue thickness & $\begin{array}{l}\text { Light limitation, } \\
\text { nutrient } \\
\text { availability }\end{array}$ & $\begin{array}{l}\text { Mean tissue thickness }(\mathrm{mm}, \pm \mathrm{SD}) \text { of massive Porites Central Great Barrier } \\
\quad \text { Reef (GBR): nearshore } 6.59 \pm 1.19, \text { offshore } 5.21 \pm 0.95\end{array}$ & $\begin{array}{l}\text { (Barnes and Lough } \\
\text { 1992) }\end{array}$ \\
\hline Surface rugosity & $\begin{array}{l}\text { Light limitation, } \\
\text { nutrient } \\
\text { availability }\end{array}$ & $\begin{array}{l}\text { Surface rugosity of massive Porites greater on nearshore compared with } \\
\text { offshore reefs. Mean tissue growth }\left(\mathrm{mm} \text { year }{ }^{-1} \pm \mathrm{SE}\right) \text { : nearshore } \\
9.20 \pm 1.66, \text { mid-shelf } 7.42 \pm 1.32 \text {, offshore } 6.87 \pm 0.14\end{array}$ & (Darke 1991) \\
\hline Coral growth & $\begin{array}{l}\text { Light limitation, } \\
\text { nutrient } \\
\text { availability }\end{array}$ & $\begin{array}{l}\text { Massive Porites: mean skeletal density }\left(\mathrm{g} \mathrm{cm}^{-3}, \pm \mathrm{SD}\right) \text { : Central GBR } \\
\text { nearshore } 1.35 \pm 0.21, \text { offshore } 1.57 \pm 0.16 . \text { Mean extension rate } \\
\left(\mathrm{mm} \text { year }{ }^{-1}, \pm \mathrm{SD}\right): \text { nearshore } 13.56 \pm 3.5 \text {, offshore } 8.22 \pm 1.02 \text {. Mean } \\
\text { calcification rate }\left(\mathrm{g} \mathrm{cm}^{-2} \text { year }^{-1}, \pm \mathrm{SD}\right) \text { : nearshore } 1.77 \pm 0.26 \text {, offshore } \\
1.28 \pm 0.12\end{array}$ & $\begin{array}{l}\text { (Lough and Barnes } \\
\text { 1992) }\end{array}$ \\
\hline Coral growth & $\begin{array}{l}\text { Dissolved } \\
\text { inorganic } \\
\text { nutrients }\end{array}$ & $\begin{array}{l}\text { S. pistillata: growth rates }\left(\mathrm{mg} \mathrm{day}^{-1}\right) \text { decreased by } 25-60 \% \text { during long- } \\
\text { term nutrient exposure }\end{array}$ & $\begin{array}{r}\text { (Ferrier-Pages } \\
\text { et al. 2000) }\end{array}$ \\
\hline $\begin{array}{l}\text { Skeletal elemental and } \\
\text { isotopic composition }\end{array}$ & Sewage & $\begin{array}{l}\text { Porites lobata: } \delta^{15} \mathrm{~N} \text { levels greater on reefs with sewage input compared with } \\
\text { five of seven Indo-Pacific reference locations }\end{array}$ & $\begin{array}{l}\text { (Heikoop et al. } \\
\text { 2000) }\end{array}$ \\
\hline Partial mortality & River exposure & $\begin{array}{l}\text { More colonies with }>50 \% \text { partial mortality adjacent to river mouths than } \\
\text { sites distant from riverine discharge }\end{array}$ & $\begin{array}{l}\text { (Nugues and } \\
\text { Roberts 2003) }\end{array}$ \\
\hline Mucus production & Sediment & $\begin{array}{l}\text { Variable species- and sediment-specific responses in situ and under } \\
\text { experimental conditions for } 42 \text { scleractinian corals }\end{array}$ & $\begin{array}{l}\text { (Stafford-Smith } \\
\text { and Ormond } \\
\text { 1992) }\end{array}$ \\
\hline \multicolumn{4}{|l|}{ Population measures } \\
\hline Population structure & $\begin{array}{l}\text { Field water quality } \\
\text { gradient }\end{array}$ & $\begin{array}{l}\text { High Island (high exposure to flood plumes) low colony density }\left(0.13 \mathrm{~m}^{-2}\right) \text {, } \\
\text { similar proportion across size classes. Fitzroy Island (low exposure to } \\
\text { flood plumes) greater colony density }\left(2.46 \mathrm{~m}^{-2}\right) \text {, population dominated } \\
(>73 \%) \text { by juvenile size classes. }\end{array}$ & (Smith et al. 2005) \\
\hline Coral diseases & $\begin{array}{l}\text { Dissolved } \\
\text { inorganic } \\
\text { nutrients }\end{array}$ & $\begin{array}{l}\text { Nutrient enrichment associated with increased aspergillosis of Gorgonia } \\
\text { ventalina and yellow band disease of Montastraea annularis and } \\
\text { M. franksii }\end{array}$ & (Bruno et al. 2003) \\
\hline Coral diseases & $\begin{array}{l}\text { Dissolved organic } \\
\text { carbon }\end{array}$ & $\begin{array}{l}\text { Species-specific responses in mortality of Montastrea annularis, Agaricia } \\
\text { tenuifolia and Porites furcata exposed to different sources of DOC. } \\
\text { Mortality increased over time suggesting chronic exposure is potentially } \\
\text { more deleterious than acute exposure }\end{array}$ & (Kuntz et al. 2005) \\
\hline
\end{tabular}


Table 2 continued

\begin{tabular}{|c|c|c|c|}
\hline Bioindicator & Stressor & Response & Source \\
\hline Coral diseases & $\begin{array}{l}\text { Dissolved organic } \\
\text { carbon }\end{array}$ & $\begin{array}{l}\text { Mortality of M. annularis fivefold greater, and microbial production rates } \\
\text { one order of magnitude greater, in DOC enriched treatments than in } \\
\text { controls }\end{array}$ & (Kline et al. 2006) \\
\hline Bioerosion & Terrestrial runoff & $\begin{array}{l}\text { Total internal bioerosion of Acropora highly variable with nearshore } \sim 4 \% \text {, } \\
\text { mid-shelf } \sim 12 \% \text {, outer reefs } \sim 1 \% \text {. }\end{array}$ & (Risk et al. 1995) \\
\hline Bioerosion & Terrestrial runoff & $\begin{array}{l}\text { Internal bioerosion in living Porites } 11 \% \text { on nearshore reefs, } 1.3 \% \text { on outer } \\
\text { reefs. }\end{array}$ & $\begin{array}{l}\text { (Sammarco and } \\
\text { Risk 1990) }\end{array}$ \\
\hline \multicolumn{4}{|l|}{ Community measures } \\
\hline $\begin{array}{l}\text { Micro- and } \\
\text { meiobenthic } \\
\text { bioindicators }\end{array}$ & $\begin{array}{l}\text { Field water quality } \\
\text { gradient }\end{array}$ & $\begin{array}{l}\text { Change in benthic foraminifera along water quality gradients. Heterotrophic } \\
\text { rotaliids and a species retaining plastids (Elphidium sp.) characteristic of } \\
\text { low light, higher nutrient conditions on turbid nearshore reefs with larger } \\
\text { symbiont-bearing taxa Amphistegina spp. and Calcarina hispida abundant } \\
\text { on clear-water outer reefs in the Whitsunday Region of GBR }\end{array}$ & $\begin{array}{l}\text { (Uthicke and } \\
\text { Nobes 2008) }\end{array}$ \\
\hline $\begin{array}{l}\text { Larval supply and } \\
\text { recruitment }\end{array}$ & Sedimentation & $\begin{array}{l}\text { Larval survival and settlement reduced in experimental treatments of high } \\
\left(100 \mathrm{mg} \mathrm{l}^{-1}\right) \text { and low }\left(50 \mathrm{mg}^{-1}\right) \text { sediments compared with controls } \\
\left(0 \mathrm{~m} \mathrm{l}^{-1}\right)\end{array}$ & (Gilmour 1999) \\
\hline $\begin{array}{l}\text { Larval supply and } \\
\text { recruitment }\end{array}$ & River exposure & $\begin{array}{l}\text { Recruitment greater on reefs distant from a river in the northern GBR } \\
\text { compared with those adjacent to river discharge }\end{array}$ & (Smith et al. 2005) \\
\hline Benthic cover & Dredging & $\begin{array}{l}\text { Coral cover decreased by } 30 \% \text { adjacent to a dredging operation. Recovery of } \\
\text { coral cover within } 22 \text { months }\end{array}$ & $\begin{array}{l}\text { (Brown et al. } \\
\text { 1990) }\end{array}$ \\
\hline Benthic cover & $\begin{array}{l}\text { Field water quality } \\
\text { gradient }\end{array}$ & $\begin{array}{l}\text { Increasing distance from two rivers, Central GBR: From reefs near the river } \\
\text { to those }>80 \mathrm{~km} \text {, macroalgae cover decreased from } 70 \pm 10 \% \text { to } 0 \% \text {, } \\
\text { octocoral cover increased from } 1 \pm 1 \% \text { to } 19 \pm 10 \% \text {, and hard coral } \\
\text { cover increased from } 4 \pm 2 \% \text { to } 31 \pm 14 \%\end{array}$ & $\begin{array}{l}\text { (van Woesik et al. } \\
\text { 1999) }\end{array}$ \\
\hline Community structure & $\begin{array}{l}\text { Field water quality } \\
\text { gradient }\end{array}$ & $\begin{array}{l}\text { Increasing distance away from two rivers, Central GBR: } 24 \text { hard coral taxa at } \\
\text { reefs near rivers, } 64 \text { hard coral taxa at reefs }>80 \mathrm{~km} \text { away from rivers }\end{array}$ & $\begin{array}{l}\text { (van Woesik et al. } \\
\text { 1999) }\end{array}$ \\
\hline Taxonomic richness & $\begin{array}{l}\text { Field water quality } \\
\text { gradient }\end{array}$ & $\begin{array}{l}\text { Regional and gradient analysis of water quality on GBR, taxonomic richness } \\
\text { of hard corals } 50 \% \text { lower in region with high nutrient and sediment loads; } \\
\text { decreased octocoral richness but increased macroalgae richness along } \\
\text { water quality gradients from low to elevated levels of nutrients and } \\
\text { sediments }\end{array}$ & $\begin{array}{l}\text { (Fabricius et al. } \\
\text { 2005) }\end{array}$ \\
\hline $\begin{array}{l}\text { Max. depth of coral- } \\
\text { reef development }\end{array}$ & $\begin{array}{l}\text { Field water quality } \\
\text { gradient }\end{array}$ & $\begin{array}{l}\text { Maximum depth of coral reef development increased from } 5.0 \mathrm{~m} \text { at coastal } \\
\text { reefs to } 25 \mathrm{~m} \text { at offshore reefs in the Whitsunday Region of GBR }\end{array}$ & $\begin{array}{l}\text { (Cooper et al. } \\
\text { 2007) }\end{array}$ \\
\hline
\end{tabular}

quality, an assessment framework (Table 3) was developed based on the five selection criteria. Each of the candidate bioindicators was scored against each criterion, and the sum of positive scores determined their final rank at a scale of 1-5, with each criterion having the same weight. Hence, a bioindicator would receive a maximum score of 5 if it responds specifically and monotonically to changing water quality, has low background variability, is practical to implement and has high ecological and public relevance. Bioindicators with a score of 4 or 5 were assigned a 'highpriority' ranking for use in either long- or short-term monitoring programmes, depending on their response time. Bioindicators that ranked 2-3 were given a 'medium priority' due to satisfying only some of the selection criteria, while a ranking of $<2$ may provide useful, often complimentary, information about the responses of corals to changes in water quality, but were considered 'lowpriority'.

\section{Genetic/colony measures}

\section{Gene expression}

Genetic biomarkers are emerging as powerful tools to identify sources of stress and measure stress responses in corals (Edge et al. 2005; Morgan et al. 2005) and their symbionts (Leggat et al. 2007 and see reviews by van Oppen and Gates 2006; Foret et al. 2007). Regulation of stress-specific genes is determined by comparing gene expression in populations exposed to environmental stressors with those at reference conditions. For example, the development of a complimentary DNA (cDNA) array containing 32 stress genes allowed the profiling of gene expression in corals exposed to changes in seawater temperature, salinity and ultraviolet light in the laboratory (Edge et al. 2005) and with increasing distance from leachate associated with a municipal dump (Morgan et al. 


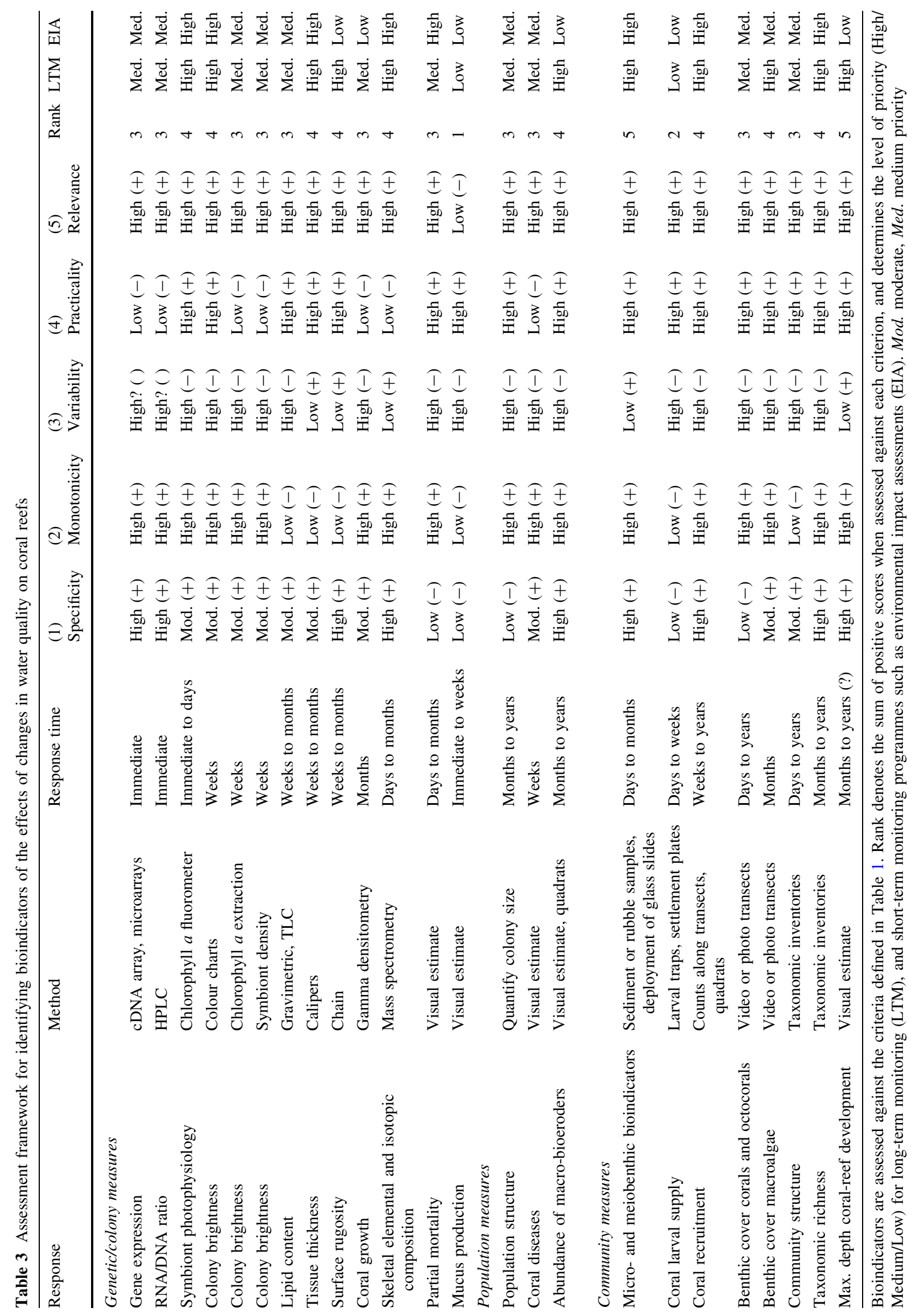


2005; Table 2). Other studies have investigated changes in the expression of large numbers of genes with DNA microarrays for stressors, such as changing seawater temperatures (Foret et al. 2007), suggesting potential for similar applications to detect changes in water quality. Gene expression ranked a medium-priority bioindicator for use in long- and short-term monitoring programmes (Table 3). Whilst it has been shown to be highly specific, the methods to detect changes in water quality require testing under field conditions and the patterns of temporal variability are not well understood.

\section{RNA/DNA ratio}

The RNA/DNA ratio is based on the principle that the amount of DNA within a cell remains invariant whereas the amount of RNA varies as a function of metabolic processes, such as protein synthesis related to growth. Under conditions favourable for coral growth, such as in clearwater with high benthic irradiance, the RNA/DNA ratio is expected to be greater than conditions where growth is limited by available light. Indeed, recent studies have demonstrated positive relationships between RNA/DNA ratio and light intensity along depth and turbidity gradients (Meesters et al. 2002; Buckley and Szmant 2004; Table 2). However, interspecific and seasonal variability, coupled with complex responses to increased heterotrophy in turbid conditions, suggests that although RNA/DNA ratios may be sensitive to changes in water quality, further research is required to better understand the sources of variability. The RNA/DNA ratio ranked a medium-priority bioindicator for use in long- and short-term monitoring programmes (Table 3), until a better understanding of interspecific and seasonal variability in this ratio is obtained. This bioindicator may, however, prove useful in EIA to measure effects of acute changes in water quality within species when values from impact locations are compared with those from reference locations.

\section{Symbiont photophysiology}

The photophysiology of coral symbionts can be characterised by several parameters each having different responses depending on exposure to the various components that comprise a change in water quality. For example, the maximum quantum yield $\left(F_{\mathrm{v}} / F_{\mathrm{m}}\right)$ decreases with increasing exposure (duration and quantity) to sediment (Philipp and Fabricius 2003) and exposure to agricultural chemicals (Jones et al. 2003; Table 2), but appears not be influenced (for cultured symbionts) by exposure to elevated levels of dissolved inorganic nutrients (Rodriguez-Roman and Iglesias-Prieto 2005). Exposing the symbionts to a series of irradiances in short (10 s)-incremental steps producing a rapid light curve can also provide detailed information on photo-acclimatory responses of corals to changes in water quality (Ralph and Gademann 2005). Quantitative parameters derived from rapid light curves include maximum photosynthetic rate $\left(\mathrm{PS}_{\max }\right)$, minimum saturating irradiance $\left(E_{\mathrm{k}}\right)$ and light utilisation coefficients $(\alpha)$ of the initial rise of the curve. Symbionts acclimatised to high irradiances are characterised by high $\mathrm{PS}_{\max }$ and $E_{\mathrm{k}}$, with low $\alpha$, but the opposite occurs for symbionts acclimatised to low-irradiance as the symbionts attempt to optimise their light capture and utilisation capability (Anthony and Hoegh-Guldberg 2003; Cooper and Ulstrup 2009). However, these parameters are influenced by variation in seawater temperature (Coles and Jokiel 1977; Warner et al. 1996; Fitt et al. 2001), flow regime (Nakamura et al. 2005), diurnal changes in benthic irradiance (Jones and Hoegh-Guldberg 2001; Lesser and Gorbunov 2001) and symbiont genotype (Frade et al. 2008; Hennige et al. 2009). Thus, these factors must be accounted for when using symbiont photophysiology to infer changes in water quality. Nevertheless, photophysiological responses are rapid (i.e. timescales of minutes to days) making these measures particularly suitable as sublethal bioindicators of changes in water quality if confounding variables are controlled. Symbiont photophysiology is, therefore, ranked a high-priority bioindicator for use in long- and short-term monitoring programmes (Table 3). Chlorophyll $a$ fluorometers can be used to quantify photophysiological responses although the application of these instruments as monitoring tools requires a high level of training and a theoretical understanding of their utility.

\section{Colony brightness}

The colour of scleractinian corals is determined by photosynthetic pigments contained in the algal endosymbionts and light-absorbing compounds in the coral tissue (e.g. Jeffrey and Haxo 1968; Salih et al. 2000; Dove et al. 2001), both of which are known to respond to changes in water quality. Concentrations of chlorophyll $a$ (and hence colour brightness) increase in response to exposure to elevated nutrients (Hoegh-Guldberg and Smith 1989; Table 2) and reduced irradiance (Falkowski and Dubinsky 1981; Dubinsky et al. 1984) whereas symbiont density may decrease in response to sedimentation (Nugues and Roberts 2003) and exposure to pollutants, such as cyanide (Cervino et al. 2003). However, symbiont density also varies with season (Stimson 1997; Brown et al. 1999; Fagoonee et al. 1999) and seawater temperature, indicating a moderate specificity to changes in water quality. Correlating colony brightness to changes in water quality also requires large spatial and temporal replication in monitoring programmes because photo-acclimatory responses occur on 
short timescales (Anthony and Hoegh-Guldberg 2003). Changes in host pigmentation in response to changes in water quality are less well documented, although Salih et al. (2006) found a modal response in levels of fluorescent pigments across a depth gradient and suggested the possibility of a dual role for these host pigments; photo-protective at high irradiances and light-amplifying at low irradiance deep depths. Notwithstanding these caveats, colony brightness ranked a high-priority bioindicator for use in long- and short-term monitoring programmes (Table 3) because colour changes can be measured with simple tools, such as colour charts (Siebeck et al. 2006), making it a useful sublethal bioindicator and a trigger for more intensive studies.

\section{Lipid content}

Corals are mixotrophic organisms that assimilate carbon from their symbionts (Muscatine 1980), the capture of zooplankton (Porter 1974) and the digestion of organic particulate matter (Tomascik and Sander 1985; Anthony 1999). Any carbon that is surplus to metabolic requirements is excreted, or stored as energy reserves in the form of lipids (Crossland 1987; Anthony and Fabricius 2000). Lipid content can change with exposure to dissolved nutrients (Achituv et al. 1994), altered light availability (Stimson 1987; Harland et al. 1992) and turbidity (Anthony and Fabricius 2000; Table 2). Saunders et al. (2005) linked differences in the ratio of non-polar storage lipids to polar structural lipids within corals, to acute changes in water quality by a relative decrease in non-polar storage lipids; the stress response was a net decrease in the amount of energy available for storage as lipids. Importantly, the use of such a ratio removes the need to normalise data, which along with potential loss of lipid mass during the gravimetric analysis, introduces another source of uncertainty into the estimate of total lipid content. Moreover, total lipid content may vary according to the production of mucus and gametes (Stimson 1987), seasons (Oku et al. 2003), and is lowest at times of high metabolic demand such as during periods of rapid growth or reproduction (Leuzinger et al. 2003). Nevertheless, this bioindicator has a rapid response time with changes occurring within weeks following changes in water quality (Anthony and Fabricius 2000; Saunders et al. 2005). Determination of total lipid content ranked a medium-priority bioindicator for use in long- and short-term monitoring programmes (Table 3 ) because of the high level of intra-colonial and seasonal variability associated with this measure. However, relative differences in the ratio of non-polar/polar lipids of corals show great potential for use in EIA when comparing impact with reference locations. Analysis of lipid content requires small samples to be collected from the coral colony, followed by analytical techniques such as gravimetry for total lipid content, or using thin-layer chromatography for determination of lipid fraction ratios (Saunders et al. 2005).

Tissue thickness of massive corals

Tissues of massive Porites have been found to be thicker on coastal reefs compared with offshore reefs, possibly because of the higher concentrations of nutrients and particulate organic matter in the coastal zone (Barnes and Lough 1992; Table 2). Many environmental factors, including irradiance, seawater temperature, water clarity, particulate and dissolved inorganic nutrient levels and sedimentation change from inshore to offshore locations, and previous studies have not resolved which of these factors is the most influential in affecting tissue thickness. Barnes and Lough (1992) suggested that massive Porites would have thicker tissue layers where particulate matter and other food items were not limited. Tissue thickness can change within a few weeks following a change in water quality (Cooper 2008), and hence this measure ranked a high-priority bioindicator for use in long- and short-term monitoring programmes (Table 3). Tissue thickness is best determined in massive Porites by removing a small core from the upward-facing surface and measuring the depth of the skeleton occupied by living tissue with callipers. However, as the thickness of the tissue layer can vary within a colony (Barnes and Lough 1992), sampling must be standardised and replicated. A limitation of this measure is that the sampling is intrusive, and so procedures that mitigate sampling effects, i.e. plugging core-holes to facilitate tissue regrowth, need to be considered.

\section{Surface rugosity of massive corals}

The surface rugosity of massive Porites increases when skeletal growth is unable to provide sufficient surface area to accommodate increased tissue growth. Several studies have shown that Porites colonies had a greater surface rugosity on coastal than offshore reefs of the Great Barrier Reef, potentially due to increased availability of nutrients and particulate organic matter (Darke 1991; Scoffin et al. 1992, Table 2), suggesting a high specificity to changes in water quality. Thus, surface rugosity ranked a high-priority bioindicator for use in long-term monitoring programmes (Table 3). It is, however, likely to be of limited use for short-term monitoring due to its slow response time. Surface rugosity can be determined by placing a piece of chain of known length on the upper surface of the colony and calculating the ratio between the horizontal and vertical chain length (Darke 1991). 
Coral growth

Irradiance is a key determinant of coral growth (Goreau and Goreau 1959; Bak 1974). However, coral growth is also indirectly affected by changes in irradiance due to variable turbidity and nutrient conditions (e.g. Marubini and Davies 1996). On the Great Barrier Reef, the growth parameters of massive Porites vary along cross-shelf gradients. For example, the skeletal density of massive Porites increases (Risk and Sammarco 1991), but the rate of linear extension and calcification decreases, with increasing distance from the coast (Lough and Barnes 1992; Table 2). However, coral growth is also influenced by variation in other parameters such as temperature, thermal stress and ocean acidification (Lough and Barnes 2000; Cooper et al. 2008a; De'ath et al. 2009) indicating a moderate specificity to changes in water quality. Coral growth ranked a medium-priority bioindicator for use in long-term monitoring, but was of low priority for short-term monitoring because of its slow response time (Table 3). Notwithstanding this, analysis of coral growth records provide important historical information on environmental changes over decades to centuries that can be used in combination with other bioindicators in long-term monitoring programmes. The coral growth parameters are generally derived from cores or slices of massive corals (Knutson et al. 1972), but can also be measured in corals with other growth forms (FerrierPages et al. 2000; Table 2). Techniques for quantifying coral growth include gamma densitometry (Chalker and Barnes 1990) to determine skeletal density, with the distance between the peaks of adjacent density bands to determine linear extension, and the product of these two parameters, linear extension and density, to estimate calcification rate.

Skeletal elemental and isotopic composition

Chemical elements incorporated from the water column into the coral skeleton can be used as retrospective bioindicators of environmental conditions (e.g. Goreau 1977; Risk et al. 2001; Cohen and McConnaughey 2003; Cohen et al. 2004). Several studies have examined the utility of the ratio of the nitrogen isotopes ${ }^{15} \mathrm{~N} /{ }^{14} \mathrm{~N}$ (known as $\delta^{15} \mathrm{~N}$ ) to hindcast changes in water quality on coral reefs (Sammarco et al. 1999; Heikoop et al. 2000; Table 2). The main sources of anthropogenic nitrogen (sewage, organic nitrogen from soil erosion and synthetic fertilisers) each produce characteristic $\delta^{15} \mathrm{~N}$ signatures that allow identification of the source of nitrogen (Heaton 1986). Sewage effluent is enriched with the heavier ${ }^{15} \mathrm{~N}$ isotope and has $\delta^{15} \mathrm{~N}$ values in the range from $+10 \%$ to $+22 \%$, soilorganic nitrogen between +4 and $+9 \%$, with synthetic fertilizers from $-4 \%$ to $+4 \%$ (Heaton 1986). For example,
Marion et al. (2005) traced the introduction of synthetic fertiliser on rice fields in Bali back to the early 1970's using $\delta^{15} \mathrm{~N}$ records in coastal corals exposed to agricultural runoff. Skeletal elemental and isotopic composition is, therefore, ranked a high-priority bioindicator for use in long- and short-term monitoring programmes (Table 3). Analyses of skeletal chemistry typically involve the collection of a small sample of coral followed by analysis using mass spectrometry to identify specific sources of pollutants on coral reefs (Risk et al. 2001).

\section{Partial mortality}

A partial mortality is a lesion in the living tissue of a coral colony that may be caused by changes in a range of environmental conditions (Hughes and Jackson 1980). Estimates of partial mortality on the surfaces of coral colonies have been used to assess the effects of water quality stressors such as sedimentation on coral reefs. Nugues and Roberts (2003) reported higher partial mortality in some coral species at sites closest to rivers compared with those at some distance from rivers (Table 2). Importantly, this response was species specific and likely to be greater in species with poor sediment-rejection abilities (Obura 2001; Nugues and Roberts 2003). Ginsburg et al. (2001), however, found great variability in the partial mortality of massive corals and suggested that for corals with a massive growth form, partial mortality was not a suitable bioindicator of changes in water quality along the Florida Reef Tract. Partial mortality can also result from injuries due to competitive interactions with other benthic organisms, feeding scars from coral predators, overgrowth by macroalgae, coral diseases, storms or other physical damage (Garzon-Ferreira et al. 2005) indicating low specificity to changes in water quality. Thus, partial mortality ranked a medium-priority bioindicator for use in long-term monitoring programmes (Table 3). Increases in rates of partial mortality are, however, likely to be rapid following acute changes in water quality such as increased sedimentation. Thus, measuring rates of change in partial mortality ranked a high-priority bioindicator for short-term monitoring and could be used as a trigger for a more intensive impact assessment. Partial mortality can be quantified by estimating the proportion of colony surface free of living tissue, or using photographic techniques to measure the area of lesions and colony surfaces.

\section{Mucus production}

Mucus is produced by some corals to clean the colony surface of sediments, or as a response to emersion during low tides, turbidity, pollutant exposure, changes in salinity and water temperatures and injury (Stafford-Smith and 
Ormond 1992; Stafford-Smith 1993; Brown and Bythell 2005). Some corals, however, will not produce mucus when stressed, or will stop producing mucus after prolonged stress. For example, sheets of mucus may only be produced by massive Porites to remove sediment when conditions are calm (Coffroth 1985), and fungid corals may cease producing mucus when cells become 'exhausted', despite ongoing exposure to stressors (Schuhmacher 1977). Mucus production by corals ranked a low priority bioindicator for use in long- and short-term monitoring programmes (Table 3). Mucus production is difficult to quantify and currently best recorded as qualitative observations. However, excess mucus production may be a useful qualitative bioindicator for short-term monitoring provided that complimentary evidence is obtained from quantitative methods.

\section{Population measures}

\section{Population structure}

The structure of a population can be defined as the number of individuals at different life-history stages. The effects of changes in water quality on coral reefs have been inferred by quantifying changes in the structure of coral populations through time (e.g. Bak and Meesters 1999; Meesters et al. 2001; Gilmour 2004). Meesters et al. (2001) found that the size-frequency distributions of coral populations closest to urban centres were negatively skewed, having fewer juveniles and more large colonies than reference locations. For some species, however, differences in size-frequency distributions were related to their life-history strategies, such as the degree to which corals invest in different modes of sexual and asexual reproduction (Gilmour 2004), or species with small, short-lived colonies (Meesters et al. 2001). In contrast, the size-frequency distributions of populations recovering from a bleaching event were skewed positively (dominated by juvenile size classes) at a location exposed to infrequent floods, whereas it was platykurtotic (flattened) at a location with a higher flood frequency (Smith et al. 2005; Table 2). Population size-frequency distributions of corals are affected by a range of other confounding variables such as flow, irradiance, connectivity to larval sources and disturbance history (Hughes 1989; Hughes and Connell 1999), indicating a low specificity to changes in water quality. Thus, population structure ranked a medium-priority bioindicator for use in long- and short-term monitoring programmes (Table 3). The population structure of a coral reef can be assessed by measuring sizes and determining the abundance of colonies along transects.

\section{Coral diseases}

Coral diseases are recognised as a major form of disturbance for coral reefs (Sutherland et al. 2004) and anthropogenic influences are considered to increase their prevalence (Green and Bruckner 2000; Bruno et al. 2003). At present, approximately 20 diseases have been identified that affect more than 100 species of corals (Sutherland et al. 2004). Most diseases are caused by pathogens such as bacteria, cyanobacteria and fungi. Pathogens can be delivered to coral reefs via terrestrial runoff (Sutherland et al. 2004), or transmitted by biological vectors (Sussman et al. 2003). Recent studies have highlighted the role of elevated levels of dissolved organic carbon, a common component of sewage and organic discharge, to tissue sloughing (symptomatic of many diseases) and increased coral mortality (Table 2; Kuntz et al. 2005; Kline et al. 2006). However, elevated water temperatures can also increase the spread and virulence of pathogens on reefs with high coral cover (Bruno et al. 2007) and reduce the immune response in corals, indicating a moderate specificity to changes in water quality. The incidence of coral disease ranked a medium-priority bioindicator for use in long-term monitoring programmes (Table 3). Notwithstanding this, relative changes in the incidence of coral diseases may provide useful information for control-impact type studies. Coral disease prevalence can be quantified as the proportion of colonies with visible disease symptoms in large quadrats or along transects (e.g. Cervino et al. 2001).

\section{Abundance of macro-bioeroders}

Bioerosion is the process of erosion of substrata by biological activity, and comprises both internal bioerosion (i.e. micro- and macroborers) and external bioerosion (i.e. grazers) (Hutchings 1986; Bellwood 1995). Rose and Risk (1985) found an increased abundance of the boring sponge Cliona delitrix on reefs associated with the discharge of untreated sewage. Similarly, the inverse relationship between the abundance of internal bioeroders and distance from the coast, in Acropora formosa and massive colonies of Porites, was attributed primarily to a greater exposure to terrestrially derived nutrients on nearshore reefs on the Great Barrier Reef (Sammarco and Risk 1990; Risk et al. 1995; Table 2). Abundances of macro-bioeroders have been shown to have a high specificity and slow-response period to spatial differences in water quality (Cooper et al. 2008b), and hence provide a useful time-integrated measure of water-quality changes. For this reason, abundance of macro-bioeroders ranked a high-priority bioindicator for use in long-term monitoring, but had medium priority for short-term monitoring because of the slow-response period (Table 3). The abundance of macro-bioeroders 
(predominantly sponges, polychaetes, sipunculans, barnacles and bivalves) can be determined with counts of external bore holes occurring in quadrats placed on the surface of living massive corals.

\section{Community measures}

Micro- and meiobenthic bioindicators

A variety of micro- and meiobenthic measures are potential bioindicators of changes in water quality. For example, the content of organic matter (Hyland et al. 2005), abundance and composition of bacteria species (Uthicke and McGuire 2007) and microphytobenthos (Bell and Elmetri 1995; Gottschalk et al. 2007) of sediments, as well as foraminifera (Cockey et al. 1996; Uthicke and Nobes 2008), amphipods (Thomas 1993) and stomatopods (Risk et al. 2001) are all potential bioindicators of changes in water quality. Indeed, some of these indicators have already been applied successfully in monitoring programmes e.g. the FORAM Index developed by Hallock et al. (2003). Whilst most micro- and meiobenthic indicators show great potential for application to coral reefs, their widespread acceptance will depend on the availability of taxonomic expertise or genetic assays, or the development of simple protocols that overcome the need for species differentiation. Recently, Uthicke and Nobes (2008) demonstrated the application of a FORAM Index to coral reefs by quantifying the disappearance of large symbiont-bearing taxa in foraminifera assemblages along a gradient of decreasing irradiance and increasing nutrient availability, from the outer to the inner Great Barrier Reef (Table 2). Micro- or meiobenthic bioindicators, especially foraminifera, were ranked high-priority bioindicators for use in long- and short-term monitoring programmes (Table 3). Methods such as the FORAM Index are based on easily quantifiable size classes, rather than species composition, thereby useful information can be obtained even by observers with limited taxonomic expertise (Hallock et al. 2003). Foraminifera communities can be quantified simply by collecting replicate sediment samples on coral reefs, which may be dried and stored for later processing.

\section{Larval supply and coral recruitment}

Many spawning corals release gametes synchronously over a few nights each year that develop into larvae and disperse for days to months before settling and metamorphosing into coral polyps. The number of larvae settling at a site is a measure of larval supply, while the number of small juvenile corals (typically defined as $<5 \mathrm{~cm}$ ) is a measure of recruitment to the community. High sedimentation, turbidity and nutrients all reduce the number of larvae produced by corals, their rates of settlement and early post-settlement survival (Babcock and Davies 1991; Hunte and Wittenberg 1992; Wittenberg and Hunte 1992). Larval supply of corals is influenced by the abundance and fecundity of adult corals on the reef and on adjacent reefs, the abundance of predators and competitors, and the physical conditions before, during and after spawning (e.g. Hughes and Jackson 1985; Hughes and Connell 1987). Consequently, there is great natural variation in the supply of larva on a coral reef. Thus, larval supply ranked a low priority bioindicator for use in monitoring programmes (Table 3 ). In contrast, larval settlement is typically the greatest on surfaces that are relatively free of sediment, i.e. vertical or downward-facing horizontal surfaces in areas of high sedimentation (Babcock and Davies 1991; Gilmour 1999; Table 2). Thus, the ratio of coral recruits on vertical, compared with upward-facing horizontal, surfaces may prove a better bioindicator of changes in sedimentation on coral reefs than settlement abundance alone, but field comparisons are required to determine suitability. Coral recruitment (i.e. the number of small juvenile corals of a given taxonomic group) ranked a high-priority bioindicator for use in long- and short-term monitoring programmes, because changes in the abundance of the smallest colony size classes reflect their susceptibility to changes in water quality such as rates of sedimentation (Table 3). Larval supply can be quantified using larvae traps (Lasker et al. 1998) or settlement plates (e.g. Babcock and Davies 1991), and changes in the number of coral recruits can be quantified within quadrats or transects, although both methods are labour intensive and require some taxonomic expertise.

\section{Benthic cover}

Benthic cover of coral-reef biota is perhaps the most widely measured parameter in coral-reef monitoring programmes (e.g. Marshall and Orr 1931; Smith et al. 1981; Bell and Elmetri 1995). Estimates of the percentage cover of benthic communities are generally calculated for hard corals, octocorals, macroalgae and sediment, and the proportion of these categories has been shown to vary with changes in water quality. For example, coral cover is known to decrease with declining water quality in the Indo-Pacific (e.g. Brown et al. 1990; van Woesik et al. 1999; Table 2). In contrast, Lirman and Fong (2007) found a negative relationship between coral cover and changes in water quality in the Florida Keys, where coral cover was significantly greater on coastal compared with offshore reefs, despite the existence of a water quality gradient. In some instances, coral cover alone may not reflect the effects of changes in water quality, because coral cover is also influenced by other forms of disturbance, which include cyclones, destructive fishing, bleaching events, predation by Acanthaster 
planci and ship groundings. Therefore, changes in coral cover have a low specificity to changes in water quality, and using it as a co-variate in water-quality assessments will require knowledge of the disturbance history. Response times of loss of coral cover vary from weeks for acute changes in water quality (Brown et al. 1990), to years for chronic exposure. Thus, benthic cover of hard corals ranked a medium-priority bioindicator for use in long- and shortterm monitoring programmes (Table 3). In contrast, increases in macroalgal cover associated with declines in water quality are well known, with perhaps the best evidence being provided by the shift in the coral reef assemblage from one dominated by hard corals to a high cover of macroalgae due to the introduction of sewage into Kaneohe Bay (Smith et al. 1981). Changes in macroalgae have a high specificity, and are highly relevant in the public perception, making it a high priority for use in long-term monitoring programmes provided the confounding influences of seasons and grazing pressure of herbivores are taken into consideration (Hughes et al. 2007).

\section{Community structure}

Community structure is defined as the relative abundance of different taxa at a location. Links are often drawn between coral community structure and exposure to water quality because species' abundances generally reflect environmental conditions (e.g. van Woesik et al. 1999; Table 2). For example, the community structure of macroalgae may be explained by responses to water quality. Fabricius et al. (2005) reported strong gradient effects in macroalgae at different spatial scales, with greater relative abundances of Rhodophyta and Chlorophyta on coastal reefs adjacent to a region exposed to elevated loads of terrestrial runoff, compared with a region with lower nutrient and sediment inputs. This measure, however, has a variable response time, with rapid changes after acute disturbances that result in mortality, and gradual shifts in response to chronic water-quality changes (Brown et al. 1990). Being a multivariate measure, the interpretation of changes in community structure requires knowledge of the biology of the individual species involved, as well as the disturbance history of a location. Thus, community structure ranked a medium-priority bioindicator for use in longand short-term monitoring programmes (Table 3). The methods to monitor coral community structure are established, and are based on standard monitoring techniques such as photo-transects (English et al. 1997).

Taxonomic richness

Taxonomic richness is defined as the number of taxa within a community. The taxonomic richness of hard corals, octocorals and macroalgae gradually change along water quality gradients in several coastal regions of the Great Barrier Reef (van Woesik et al. 1999; Fabricius et al. 2005). For example, the taxonomic richness of octocorals with zooxanthellae declined with increasing turbidity and sedimentation (Fabricius et al. 2005; Table 2). Existing studies suggest that the taxonomic richness of hard corals, octocorals and macroalgae have a high specificity to changes in water quality. In addition, decreases in taxonomic richness will occur in response to both chronic and acute reductions in water quality, either because of rapid mortality or reduced settlement success of the most susceptible species. Taxonomic richness is, therefore, considered a high-priority bioindicator for use in long- and short-term monitoring programmes (Table 3), although extensive and ongoing observer training is required to identify and quantify the different taxa and cross calibration is necessary to achieve any consistency. As with community structure, the methods to monitor taxonomic richness are established (English et al. 1997), but require high-level taxonomic expertise.

\section{Maximum depth of coral-reef development}

The maximum depth of seagrass distribution has been used as a bioindicator of estuarine health (Abal and Dennison 1996), and a similar approach has been used for coral communities to infer changes in water quality on coral reefs (Kleypas 1996; van Woesik et al. 1999; Cooper et al. 2007). Coral growth and distribution is determined by available irradiance (Yentsch et al. 2002), and the maximum depth of coral reef development can be defined as the zone of transition from zooxanthellate hard corals to azooxanthellate filter feeders along a depth gradient. On the Great Barrier Reef, the maximum depth of coral-reef development increased almost fivefold within a group of inshore islands along a gradient from low irradiance and elevated nutrients at nearshore locations, to high irradiance and low nutrients at outer locations (Cooper et al. 2007; Table 2). The response time of changes in maximum depth of coral growth is most likely to be on a timescale of months to years. Thus, the maximum depth of coral-reef development ranked a high priority for use in long-term monitoring, but was a low priority for use in short-term monitoring programmes (Table 3). The maximum depth of coral reef development can be quantified by visual estimates or with transects along a depth gradient.

\section{Conclusions}

Each of the bioindicators identified here has a different response time (i.e. from near instantaneous to years) and 
specificity to changes in water quality, and the final choice of bioindicators must depend on the specific objective and timeframe available for a monitoring programme. Responses that are specific to disturbances such as nutrient availability, sedimentation and turbidity and that demonstrate a rapid response time, can provide an early warning of changes in water quality. In particular, sublethal bioindicators that reflect rapid changes at the genetic/colony level of selected species may be among the most effective ways to pre-empt mortality of corals and impacts to the wider community. In addition, understanding the processes acting within colonies and among the life-history stages of a selected species will provide a better understanding of the consequences of changes in water quality on populations and coral-reef communities. The comparison of responses from a composite of bioindicators will provide the most useful information on the status and trends of reef ecosystems. As the extent of water-quality degradation increases, so does the scale at which the responses are manifested, and the time taken for the system to return to its previous state when the stressors are removed. Responses to small changes in water quality may be best

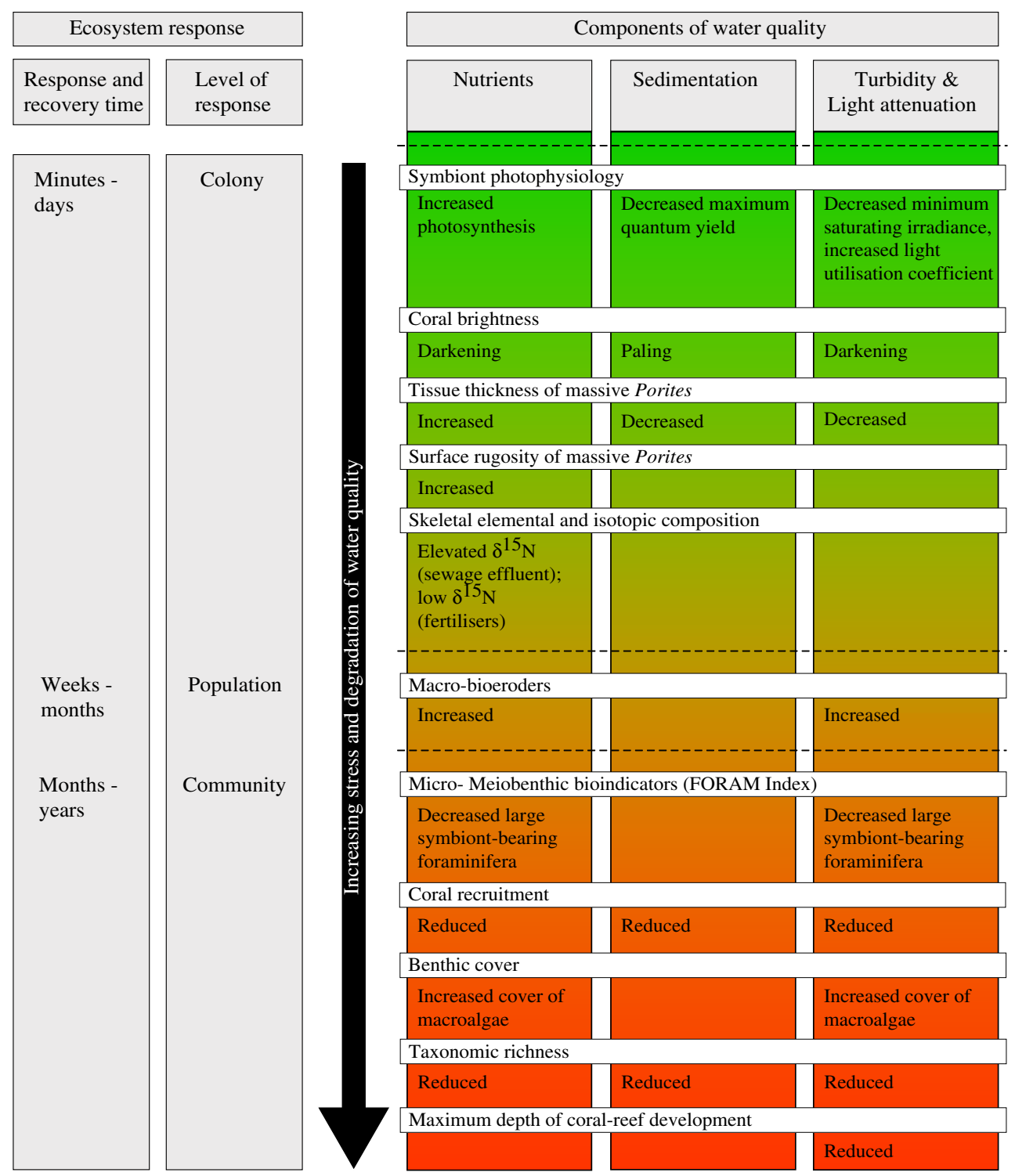

Fig. 2 Conceptual model of coral bioindicators to indicate increasing exposure to the key components of water quality. Responses are presented in increasing order of effect from stress to mortality resulting from increasing levels of stressors. Responses will depend on both the magnitude and duration of changes in the levels of stressors (e.g. Kuntz et al. 2005). All the responses will first be evident at the genetic/colony level and then in the wider community. Sublethal responses, therefore, may pre-empt more severe effects at the population and community level and can be used to describe shifts in ecosystem condition from healthy (green) to degraded (red) conditions 
measured by focusing on rapid sublethal effects at the genetic/colony level in the most susceptible species or life stages; when the stressors are removed, then the condition of these organisms may rapidly return to their previous state. With further decreases in water quality, responses will be measured as partial mortality or mortality of organisms in an increasing number of species or life stages, which becomes evident at the scale of populations and communities, and these signals will remain measurable for months to years after the stressors are removed. Finally, extreme decreases in water quality produce widespread mortality across a range of organisms that will be evident at the level of entire communities and as a shift in ecosystem state; the time taken for the response to be manifest will vary between chronic or acute events, but recovery, when the stressors are removed, is likely to occur slowly. This is best conceptualised when the bioindicators are represented against increasing levels of stressors, from sublethal stress to mortality (Fig. 2). Exposure to a low-level stress will first invoke a response at the genetic and colony level, such as symbiont photophysiology and coral brightness. As stress increases, either in terms of duration or intensity, responses at the population and community level may become evident through reduced juvenile densities, changes in the community structure, through the loss of susceptible species, increased macroalgal abundances, reduced abundances of large symbiont-bearing foraminifera, and a reduction in the maximum depth of coral-reef development. Response time is, therefore, a critical criterion that underpins bioindicator selection in any environmental monitoring. Moreover, exposure to changes in water quality may invoke different responses in some groups, e.g. elevated nutrient concentrations and turbidity decreases coral brightness, while sedimentation stress increases brightness (through bleaching) on upward facing surfaces. Hence, important information on the specific forms of stress can be gained by investigating the direction and magnitude of responses relative to reference conditions.

This review has identified 11 measures as high-priority bioindicators that should be considered for inclusion into long-term monitoring programmes. These are: symbiont photophysiology, colony brightness of corals, tissue thickness and surface rugosity of massive corals, skeletal elemental and isotopic composition, abundance of macrobioeroders, coral recruitment, micro- and meiobenthic bioindicators such as foraminifera, macroalgal cover, taxonomic richness of corals and the depth of coral-reef development. For short-term monitoring programmes such as required for EIA that aim to quantify effects of acute disturbances on coral communities, eight priority bioindicators were identified as: symbiont photophysiology, colony brightness of corals, tissue thickness of massive corals, skeletal elemental and isotopic composition, partial mortality, micro- and meiobenthic bioindicators, coral recruitment and taxonomic richness of corals. The difference between the two suites of bioindicators primarily reflects differences in the response time. Short-term monitoring programmes would be best served with sublethal bioindicators or those evident in the most susceptible species, which have rapid response times. In the case of acute changes in water quality, the exceedence of some pre-determined threshold for a bioindicator may trigger a management response that could be used to limit further impacts. In contrast, monitoring the biological consequences of chronic exposure to lowered water quality as part of long-term monitoring programmes would be best based on bioindicators with slower response times coupled with a suite of sublethal bioindicators to provide an early indication of ecological change. Pomeroy et al. (2004) identified a range of measures that also included taxonomic richness and coral recruitment as priority biophysical indicators for assessing the effectiveness of marine protected areas. However, this review has also identified that sublethal measures have important applications in monitoring programmes. For either short- or longer-term monitoring programmes, assessments should be based on deviation from reference values (historic data or reference locations), while also controlling for other changes in physical and biological conditions that affect the specificity and variability of the response. In both cases, an assessment framework, such as the one suggested here, should provide the basis for the selection of a suite of bioindicators to be used when assessing the consequences of changes in water quality around coral reefs.

Acknowledgements This study was funded by the Environmental Protection Authority of Western Australia, the Marine and Tropical Sciences Research Facility and the Australian Institute of Marine Science. An earlier version of the manuscript benefited greatly from the comments of M. Lincoln Smith, H. Sweatman, K. Ulstrup, three anonymous reviewers and an editorial contribution by $\mathrm{R}$. van Woesik.

\section{References}

Abal EG, Dennison WC (1996) Seagrass depth range and water quality in southern Moreton Bay, Queensland, Australia. Mar Freshw Res 47:763-771

Achituv Y, Ben-Zion M, Mizrahi L (1994) Carbohydrate, lipid, and protein composition of zooxanthellae and animal fractions of the coral Pocillopora damicornis exposed to ammonium enrichment. Pac Sci 48:224-233

Anthony KRN (1999) Coral suspension feeding on fine particulate matter. J Exp Mar Biol Ecol 232:85-106

Anthony KRN, Fabricius KE (2000) Shifting roles of heterotrophy and autotrophy in coral energetics under varying turbidity. J Exp Mar Biol Ecol 252:221-253

Anthony KRN, Hoegh-Guldberg O (2003) Kinetics of photoacclimation in corals. Oecologia 134:23-31 
Babcock R, Davies P (1991) Effects of sedimentation on settlement of Acropora millepora. Coral Reefs 9:205-208

Bak RPM (1974) Available light and other factors influencing growth of stony corals through the year in Curacaco. Proc 2nd Int Coral Reef Symp 2:229-233

Bak RPM, Meesters EH (1999) Population structure as a response of coral communities to global change. Am Zool 39:56-65

Barnes DJ, Lough JM (1992) Systematic variations in the depth of skeleton occupied by coral tissue in massive colonies of Porites from the Great Barrier Reef. J Exp Mar Biol Ecol 159:113-128

Bell PRF, Elmetri I (1995) Ecological indicators of large-scale eutrophication in the Great Barrier Reef lagoon. Ambio 24:208215

Bellwood DR (1995) Carbonate transport and within-reef patterns of bioerosion and sediment release by parrotfishes (Family Scaridae) on the Great Barrier Reef. Mar Ecol Prog Ser 117:127-136

Brown BE (1997) Adaptations of reef corals to physical environmental stress. Adv Mar Biol 31:221-300

Brown BE, Bythell JC (2005) Perspectives on mucus secretion in reef corals. Mar Ecol Prog Ser 296:291-309

Brown BE, Le Tissier MDA, Scoffin TP, Tudhope AW (1990) Evaluation of the environmental impact of dredging on intertidal coral reefs at Ko Phuket, Thailand, using ecological and physiological parameters. Mar Ecol Prog Ser 65:273-281

Brown BE, Dunne RP, Ambarsari I, Le Tissier MDA, Satapoomin U (1999) Seasonal fluctuations in environmental factors and variations in symbiotic algae and chlorophyll pigments in four Indo-Pacific coral species. Mar Ecol Prog Ser 191:53-69

Bruno JF, Petes LE, Harvell D, Hettinger A (2003) Nutrient enrichment can increase the severity of coral diseases. Ecol Lett 6:1056-1061

Bruno JF, Selig ER, Casey KS, Page CA, Willis BL, Harvell CD, Sweatman H, Melendy AM (2007) Thermal stress and coral cover as drivers of coral disease outbreaks. PLoS Biol 5:e124. doi:110.1371/journal.pbio.0050124

Buckley BA, Szmant AM (2004) RNA/DNA ratios as indicators of metabolic activity in four species of Caribbean reef-building corals. Mar Ecol Prog Ser 282:143-149

Cervino J, Goreau TJ, Nagelkerken I, Smith GW, Hayes R (2001) Yellow band and dark spot syndromes in Caribbean corals: distribution, rate of spread, cytology, and effects on abundance and division rate of zooxanthellae. Hydrobiologia 460:53-63

Cervino JM, Hayes RL, Honovitch M, Goreau TJ, Jones S, Rubec PJ (2003) Changes in zooxanthellae density, morphology, and mitotic index in hermatypic corals and anemones exposed to cyanide. Mar Pollut Bull 46:573-586

Chalker BE, Barnes DJ (1990) Gamma densitometry for the measurement of skeletal density. Coral Reefs 9:11-23

Chessman BC, Growns JE, Kotlash AR (1997) Objective derivation of macroinvertebrate family sensitivity grade numbers for the SIGNAL biotic index: application to the Hunter River system, New South Wales. Mar Freshw Res 48:159-172

Cockey E, Hallock P, Lidz BH (1996) Decadal-scale changes in benthic foraminiferal assemblages off Key Largo, Florida. Coral Reefs 15:237-248

Coffroth MA (1985) Mucous sheet formation on poritid corals: effects of altered salinity and sedimentation. Antenne Museum-EPHE, Moorea (French Polynesia)

Cohen AL, McConnaughey TA (2003) Geochemical perspectives on coral mineralization. In: Dove PM, Weiner S, deYoreo JJ (eds) Reviews in mineralogy and geochemistry 54:151-187

Cohen AL, Smith SR, McCartney MS, van Etten J (2004) How brain corals record climate: an integration of skeletal structure, growth and chemistry of Diploria labyrinthiformis from Bermuda. Mar Ecol Prog Ser 271:147-158
Coles SL, Jokiel PL (1977) Effects of temperature on photosynthesis and respiration in hermatypic corals. Mar Biol 43:209-216

Cooper TF (2008) Coral bioindicators of environmental conditions on coastal coral reefs. PhD thesis, James Cook University, p 202

Cooper TF, Ulstrup KE (2009) Mesoscale variation in the photophysiology of the reef building coral Pocillopora damicornis along an environmental gradient. Estuar Coast Shelf Sci 83:186-196. doi: 10.1016/j.ecss.2009.03.015

Cooper TF, Uthicke S, Humphrey C, Fabricius KE (2007) Gradients in water column nutrients, sediment parameters, irradiance and coral reef development in the Whitsunday Region, central Great Barrier Reef. Estuar Coast Shelf Sci 74:458-470

Cooper TF, De'ath G, Fabricius KE, Lough JM (2008a) Declining coral calcification in massive Porites in two nearshore regions of the northern Great Barrier Reef. Global Change Biol 14:529-538

Cooper TF, Ridd PV, Ulstrup KE, Humphrey C, Slivkoff M, Fabricius KE (2008b) Temporal dynamics in coral bioindicators for water quality on coastal coral reefs of the Great Barrier Reef. Mar Freshw Res 59:703-716

Crossland CJ (1987) In situ release of mucus and DOC-lipid from the corals Acropora variabilis and Stylophora pistillata in different light regimes. Coral Reefs 6:35-42

Darke WM (1991) Growth and growth form of the massive coral Porites. PhD thesis, James Cook University, p 161

De'ath G, Lough JM, Fabricius KE (2009) Declining coral calcification on the Great Barrier Reef. Science 323:116-119

Dove SG, Hoegh-Guldberg O, Ranganathan S (2001) Major colour patterns of reef-building corals are due to a family of GFP-like proteins. Coral Reefs 19:197-204

Dubinsky Z, Falkowski PG, Porter JW, Muscatine L (1984) Absorption and utilisation of radiant energy by light- and shade-adapted colonies of the hermatypic coral Stylophora pistillata. Proc R Soc Lond, B 222:203-214

Edge SE, Morgan MB, Gleason DF, Snell TW (2005) Development of a coral cDNA array to examine gene expression profiles in Montastraea faveolata exposed to environmental stress. Mar Pollut Bull 51:507-523

English S, Wilkinson C, Baker V (1997) Survey manual for tropical marine resources, 2nd edn. Australian Institute of Marine Science, Townsville

Erdmann MV, Caldwell RL (1997) Stomatopod crustaceans as bioindicators of marine pollution stress on coral reefs. Proc 8th Int Coral Reef Symp 2:1521-1526

Fabricius KE (2005) Effects of terrestrial runoff on the ecology of corals and coral reefs: review and synthesis. Mar Pollut Bull 50:125-146

Fabricius KE, De'ath G, McCook L, Turak E, Williams DM (2005) Changes in algal, coral and fish assemblages along water quality gradients on the inshore Great Barrier Reef. Mar Pollut Bull 51:384-398

Fagoonee I, Wilson HB, Hassell MP, Turner JR (1999) The dynamics of zooxanthellae populations: a long-term study in the field. Science 283:843-845

Falkowski PG, Dubinsky Z (1981) Light-shade adaptation of Stylophora pistillata, a hermatypic coral from the Gulf of Eilat. Nature 289:172-174

Ferrier-Pages C, Gattuso JP, Dallot S, Jaubert J (2000) Effect of nutrient enrichment on growth and photosynthesis of the zooxanthellate coral Stylophora pistillata. Coral Reefs 19:103113

Fitt WK, Brown BE, Warner ME, Dunne RP (2001) Coral bleaching: interpretation of thermal tolerance limits and thermal thresholds in tropical corals. Coral Reefs 20:51-65

Foret S, Kassahn KS, Grasso LC, Hayward DC, Iguchi A, Ball EE, Miller DJ (2007) Genomic and microarray approaches to coral reef conservation biology. Coral Reefs 26:475-486 
Frade PR, De Jongh F, Vermeulen F, Van Bleijswijk J, Bak RPM (2008) Variation in symbiont distribution between closely related coral species over large depth ranges. Mol Ecol 17:691-703

Garzon-Ferreira J, Zea S, Diaz JM (2005) Incidence of partial mortality and other health indicators in hard-coral communities of four southwestern Caribbean atolls. Bull Mar Sci 76:105-122

Gilmour J (1999) Experimental investigation into the effects of suspended sediment on fertilisation, larval survival and settlement in a scleractinian coral. Mar Biol 3:451-462

Gilmour JP (2004) Size-structures of populations of the mushroom coral Fungia fungites: the role of disturbance. Coral Reefs 23:493-504

Ginsburg RN, Gischler E, Kiene WE (2001) Partial mortality of massive reef-building corals: an index of patch reef condition, Florida reef tract. Bull Mar Sci 69:1149-1173

Goreau TJ (1977) Coral skeletal chemistry: physiological and environmental regulation of stable isotopes and trace metals in Montastrea annularis. Proc R Soc Lond, B 196:291-315

Goreau TF, Goreau NI (1959) The physiology of skeleton formation in corals. II. Calcium deposition by hermatypic corals under various conditions in the reef. Biol Bull (Woods Hole) 117:239259

Gottschalk S, Uthicke S, Heimann K (2007) Benthic diatom community composition in three regions of the Great Barrier Reef, Australia. Coral Reefs 26:345-357

Green EP, Bruckner AW (2000) The significance of coral disease epizootiology for coral reef conservation. Biol Conserv 96:347361

Hallock P, Lidz BH, Cockey-Burkhard EM, Donnelly KB (2003) Foraminifera as bioindicators in coral reef assessment and monitoring: The foram index. Environ Monit Assess 81:221-238

Harland AD, Davies PS, Fixter LM (1992) Lipid content of some Caribbean corals in relation to depth and light. Mar Biol 113:357-361

Heaton THE (1986) Isotopic studies of nitrogen pollution in the hydrosphere and atmosphere: a review. Chem Geol (Isotope Geoscience Section) 59:87-102

Heikoop JM, Risk MJ, Lazier AV, Edinger EN, Jompa J, Limmon GV, Dunn JJ, Browne DR, Schwarcz HP (2000) Nitrogen-15 signals of anthropogenic nutrient loading in reef corals. Mar Pollut Bull 40:628-636

Hennige SJ, Suggett DJ, Warner ME, McDougall KE, Smith DJ (2009) Photobiology of Symbiodinium revisited: bio-physical and bio-optical signatures. Coral Reefs 28:179-195

Hoegh-Guldberg O, Smith GJ (1989) Influence of the population density of zooxanthellae and supply of ammonium on the biomass and metabolic characteristics of the reef corals Seriatopora hystrix and Stylophora pistillata. Mar Ecol Prog Ser 57:173-186

Hughes TP (1989) Community structure and diversity of coral reefs: the role of history. Ecology 70:275-279

Hughes TP, Connell JH (1987) Population dynamics based on size or age? A reef-coral analysis. Am Nat 129:818-829

Hughes TP, Connell JH (1999) Multiple stressors on coral reefs: a long-term perspective. Limnol Oceanogr 44:461-488

Hughes TP, Jackson JBC (1980) Do corals lie about their age? Some demographic consequences of partial mortality, fission, and fusion. Science 209:713-715

Hughes TP, Jackson JBC (1985) Population dynamics and life histories of foliaceous corals. Ecol Monogr 55:141-166

Hughes TP, Rodrigues MJ, Bellwood DR, Ceccarelli D, HoeghGuldberg O, McCook L, Moltschaniwskyj N, Pratchett MS, Steneck RS, Willis B (2007) Phase shifts, herbivory, and the resilience of coral reefs to climate change. Curr Biol 17:360-365
Hunte W, Wittenberg M (1992) Effects of eutrophication and sedimentation on juvenile corals. 2. Settlement. Mar Biol 114:625-631

Hutchings PA (1986) Biological destruction of coral reefs. A review. Coral Reefs 4:239-252

Hyland J, Balthis L, Karakassis I, Magni P, Petrov A, Shine J, Vestergaard O, Warwick R (2005) Organic carbon content of sediments as an indicator of stress in the marine benthos. Mar Ecol Prog Ser 295:91-103

Jameson SC, Kelty RA (2004) A review of indicators of land-based pollution stress on coral reefs. Joint EPA/NOAA/USGS/DOI Workshop on Assessing Pollution Stress on Coral Reefs, Honolulu, Hawaii 2004. NOAA, Silver Spring, MD, p 77

Jameson SC, Erdmann MV, Gibson GRJ, Potts KW (1998) Development of biological criteria for coral reef ecosystem assessment. USEPA, Office of Science and Technology, Health and Ecological Criteria Division, Washington, DC

Jameson SC, Erdmann MV, Karr JR, Potts KW (2001) Charting a course toward diagnostic monitoring: a continuing review of coral reef attributes and a research strategy for creating coral reef indexes of biotic integrity. Bull Mar Sci 69:701-744

Jeffrey SW, Haxo FT (1968) Photosynthetic pigments of symbiotic dinoflagellates (zooxanthellae) from corals and clams. Biol Bull 135:149-165

Jones RJ, Hoegh-Guldberg O (2001) Diurnal changes in the photochemical efficiency of the symbiotic dinoflagellates (Dinophyceae) of corals: photoprotection, photoinactivation and the relationship to coral bleaching. Plant Cell Environ 24:89-99

Jones GP, Kaly UL (1996) Criteria for selecting marine organisms in biomonitoring studies. In: Schmitt RJ, Osenberg CW (eds) Detecting ecological impacts: concepts and applications in coastal habitats. Academic Press, New York, pp 29-48

Jones RJ, Muller J, Haynes D, Schreiber U (2003) Effects of herbicides diuron and atrazine on corals of the Great Barrier Reef, Australia. Mar Ecol Prog Ser 251:153-167

Kleypas J (1996) Coral reef development under naturally turbid conditions: fringing reefs near Broad Sound, Australia. Coral Reefs 15:153-167

Kline DI, Kuntz NM, Breitbart M, Knowlton N, Rohwer F (2006) Role of elevated organic carbon levels and microbial activity in coral mortality. Mar Ecol Prog Ser 314:119-125

Knutson DW, Buddemeier RW, Smith SV (1972) Coral chronometers: seasonal growth bands in reef corals. Science 177:270-272

Kuntz NM, Kline DI, Sandin SA, Rohwer F (2005) Pathologies and mortality rates caused by organic carbon and nutrient stressors in three Caribbean coral species. Mar Ecol Prog Ser 294:173-180

Lapointe BE (1997) Nutrient thresholds for bottom-up control of macroalgal blooms on coral reefs in Jamaica and southeast Florida. Limnol Oceanogr 42:1119-1131

Lasker HR, Kim K, Coffroth MA (1998) Production, settlement, and survival of plexaurid gorgonian recruits. Mar Ecol Prog Ser 162:111-123

Leggat W, Hoegh-Guldberg O, Dove S, Yellowlees D (2007) Analysis of an EST library from the dinoflagellate (Symbiodinium sp.) symbiont of reef-building corals. J Phycol 43:1010 1021

Lesser MP, Gorbunov MY (2001) Diurnal and bathymetric changes in chlorophyll fluorescence yields of reef corals measured in situ with a fast repetition rate fluorometer. Mar Ecol Prog Ser 212:69-77

Leuzinger S, Anthony KR, Willis BL (2003) Reproductive energy investment in corals: scaling with module size. Oecologia 136:524-531

Lirman D, Fong P (2007) Is proximity to land-based sources of coral stressors an appropriate measure of risk to coral reefs? An 
example from the Florida Reef Tract. Mar Pollut Bull 54:779791

Lough JM, Barnes DJ (1992) Comparisons of skeletal density variations in Porites from the central Great Barrier Reef. J Exp Mar Biol Ecol 155:1-25

Lough JM, Barnes DJ (2000) Environmental controls on growth of the massive coral Porites. J Exp Mar Biol Ecol 245:225-243

Loya Y (1976) Effects of water turbidity and sedimentation on the community structure of Puerto Rican corals. Bull Mar Sci $26: 450-466$

Loya Y, Lubinevsky H, Rosenfeld M, Kramarsky-Winter E (2004) Nutrient enrichment caused by in situ fish farms at Eilat, Red Sea is detrimental to coral reproduction. Mar Pollut Bull 49:344-353

Marion GS, Dunbar RB, Mucciarone DA, Kremer JN, Lansing JS, Arthawiguna A (2005) Coral skeletal delta $15 \mathrm{~N}$ reveals isotopic traces of an agricultural revolution. Mar Pollut Bull 50:931-944

Marshall SM, Orr AP (1931) Sedimentation on the Low Isles and its relation to coral growth. British Museum (Natural History) Scientific Report 1:94-133

Marubini F, Davies PS (1996) Nitrate increases zooxanthellae population density and reduces skeletogenesis in corals. Mar Biol 127:319-328

McCook LJ (1999) Macroalgae, nutrients and phase shifts on coral reefs: scientific issues and management consequences for the Great Barrier Reef. Coral Reefs 4:357-367

McCulloch M, Fallon S, Wyndham T, Hendy E, Lough J, Barnes D (2003) Coral record of increased sediment flux to the inner Great Barrier Reef since European settlement. Nature 421:727-730

Meesters EH, Hilterman M, Kardinaal E, Keetman M, de Vries M, Bak RPM (2001) Colony size-frequency distributions of scleractinian coral populations: spatial and interspecific variation. Mar Ecol Prog Ser 209:43-54

Meesters EH, Nieuwland G, Duineveld GCA, Kok A, Bak RPM (2002) RNA/DNA ratios of scleractinian corals suggest acclimatisation/adaptation in relation to light gradients and turbidity regimes. Mar Ecol Prog Ser 227:233-239

Morgan MB, Edge SE, Snell TW (2005) Profiling differential gene expression of corals along a transect of waters adjacent to the Bermuda municipal dump. Mar Pollut Bull 51:524-533

Muscatine L (1980) Productivity of zooxanthellae. In: Falkowski PG (ed) Primary productivity in the sea. Plenum Press, New York, pp 381-402

Nakamura T, van Woesik R, Yamasaki H (2005) Photoinhibition of photosynthesis is reduced by water flow in the reef-building coral Acropora digitifera. Mar Ecol Prog Ser 301:109-118

Nugues MM, Roberts CM (2003) Partial mortality in massive reef corals as an indicator of sediment stress on coral reefs. Mar Pollut Bull 46:314-323

Obura DO (2001) Can differential bleaching and mortality among coral species offer useful indicators for assessment and management of reefs under stress? Bull Mar Sci 69:421-442

Oku H, Yamashiro H, Onaga K, Sakai K, Iwasaki H (2003) Seasonal changes in the content and composition of lipids in the coral Goniastrea aspera. Coral Reefs 22:83-85

Philipp E, Fabricius KE (2003) Photophysiological stress in scleractinian corals in response to short-term sedimentation. J Exp Mar Biol Ecol 287:57-78

Pomeroy RS, Parks JE, Watson LM (2004) How is your MPA doing? A guidebook of natural and social indicators for evaluating marine protected area management effectiveness, IUCN, Gland, Switzerland and Cambridge, UK, p 216

Porter JW (1974) Zooplankton feeding by the Caribbean reef-building coral Montastrea cavernosa. Proc 2nd Int Coral Reef Symp 1: $111-126$

Ralph PJ, Gademann R (2005) Rapid light curves: a powerful tool to assess photosynthetic activity. Aquat Bot 82:222-237
Richmond RH (1993) Coral reefs - present problems and future concerns resulting from anthropogenic disturbance. Am Zool 33:524-536

Risk MJ, Sammarco PW (1991) Cross-shelf trends in skeletal density of the massive coral Porites lobata from the Great Barrier Reef. Mar Ecol Prog Ser 69:195-200

Risk MJ, Sammarco PW, Edinger EN (1995) Bioerosion in Acropora across the continental shelf of the Great Barrier Reef. Coral Reefs 14:79-86

Risk MJ, Heikoop JM, Edinger EN, Erdmann MV (2001) The assessment 'toolbox': community-based reef evaluation methods coupled with geochemical techniques to identify sources of stress. Bull Mar Sci 69:443-458

Rodriguez-Roman A, Iglesias-Prieto R (2005) Regulation of photochemical activity in cultured symbiotic dinoflagellates under nitrate limitation and deprivation. Mar Biol 146:1063-1073

Rose CS, Risk MJ (1985) Increase in Cliona delitrix infestation of Montastrea cavernosa heads on an organically polluted portion of the Grand Cayman fringing reef. PSZNI Mar Ecol 6:345-362

Salih A, Larkum A, Cox G, Kühl M, Hoegh-Guldberg O (2000) Fluorescent pigments in corals are photoprotective. Nature 408:850-853

Salih A, Cox G, Szymczak R, Coles SL, Baird AH, Dunstan A, Cocco G, Mills J, Larkum A (2006) The role of host-based color and fluorescent pigments in photoprotection and in reducing bleaching stress in corals. Proc 10th Int Coral Reef Symp: 746-756

Sammarco PW, Risk MJ (1990) Large-scale patterns in internal bioerosion of Porites: cross continental shelf trends on the Great Barrier Reef. Mar Ecol Prog Ser 59:145-156

Sammarco PW, Risk MJ, Schwarcz HP, Heikoop JM (1999) Crosscontinental shelf trends in coral delta super(15)N on the Great Barrier Reef: further consideration of the reef nutrient paradox. Mar Ecol Prog Ser 180:131-138

Saunders SM, Radford B, Bourke SA, Thiele Z, Bech T, Mardon J (2005) A rapid method for determining lipid fraction ratios of hard corals under varying sediment and light regimes. Environ Chem 2:331-336

Schaffelke B (1999) Short-term nutrient pulses as tools to assess responses of coral reef macroalgae to enhanced nutrient availability. Mar Ecol Prog Ser 182:305-310

Schuhmacher H (1977) Ability in fungiid corals to overcome sedimentation. Proc 3rd Int Coral Reef Symp: 503-509

Scoffin TP, Tudhope AW, Brown BE, Chansang H, Cheeney RF (1992) Patterns and possible environmental controls of skeletogenesis of Porites lutea, South Thailand. Coral Reefs 11:1-11

Siebeck UE, Marshall NJ, Klueter A, Hoegh-Guldberg O (2006) Monitoring coral bleaching using a colour reference card. Coral Reefs 25:453-460

Simpson JC, Norris RH (2000) Biological assessment of river quality: development of AUSRIVAS models and outputs. In: Wright JE, Sutcliffe DW, Furse MT (eds) Assessing the biological quality of fresh waters: RIVPACS and other techniques. Freshwater Biological Association, Ambleside, UK, pp 125-142

Smith SV, Kimmerer WJ, Laws EA, Brock RE, Walsh TW (1981) Kaneohe Bay sewage diversion experiment: perspectives on ecosystem responses to nutritional perturbation. Pac Sci 35:279402

Smith LD, Devlin M, Haynes D, Gilmour JP (2005) A demographic approach to monitoring the health of coral reefs. Mar Pollut Bull 51:399-407

Stafford-Smith MG (1993) Sediment-rejection efficiency of 22 species of Australian scleractinian corals. Mar Biol 115:229 243

Stafford-Smith MG, Ormond RFG (1992) Sediment-rejection mechanisms of 42 species of Australian scleractinian corals. Aust J Mar Freshw Res 43:683-705 
Stimson JS (1987) Location, quantity and rate of change in quantity of lipids in tissue of Hawaiian hermatypic corals. Bull Mar Sci 41:889-904

Stimson J (1997) The annual cycle of density of zooxanthellae in the tissues of field and laboratory-held Pocillopora damicornis (Linnaeus). J Exp Mar Biol Ecol 214:35-48

Sussman M, Loya Y, Fine M, Rosenberg E (2003) The marine fireworm Hermodice carunculata is a winter reservoir and spring-summer vector for the coral-bleaching pathogen Vibrio shiloi. Environ Microbiol 5:250-255

Sutherland KP, Porter JW, Torres C (2004) Disease and immunity in Caribbean and Indo-Pacific zooxanthellate corals. Mar Ecol Prog Ser 266:273-302

Thomas JD (1993) Biological monitoring and tropical biodiversity in marine environments: a critique with recommendations, and comments on the use of amphipods as bioindicators. J Nat Hist 27:795-806

Tomascik T, Sander F (1985) Effects of eutrophication on reefbuilding corals. 1. Growth rate of the reef-building coral Montastrea annularis. Mar Biol 87:143-155

Uthicke S, McGuire K (2007) Bacterial communities in Great Barrier Reef calcareous sediments: contrasting 16S rDNA libraries from nearshore and outer shelf reefs. Estuar Coast Shelf Sci 72:188200

Uthicke S, Nobes K (2008) Benthic Foraminifera as ecological indicators for water quality on the Great Barrier Reef. Estuar Coast Shelf Sci 78:763-773

van Oppen MJH, Gates RD (2006) Conservation genetics and the resilience of reef-building corals. Mol Ecol 15:3863-3883

van Woesik R, Tomascik T, Blake S (1999) Coral assemblages and physico-chemical characteristics of the Whitsunday Islands: evidence of recent community changes. Mar Freshw Res 50:427-440

Warner ME, Fitt WK, Schmidt GW (1996) The effects of elevated temperature on the photosynthetic efficiency of zooxanthellae in hospite from four different species of reef coral: a novel approach. Plant Cell Environ 19:291-299

Wittenberg M, Hunte W (1992) Effects of eutrophication and sedimentation on juvenile corals. 1. Abundance, mortality and community structure. Mar Biol 112:131-138

Yentsch CS, Yentsch CM, Cullen JJ, Lapointe B, Phinney DA, Yentsch SW (2002) Sunlight and water transparency: cornerstones in coral research. J Exp Mar Biol Ecol 268:171-183 